\title{
Small Bowel Lymphoma Coupled with Incidental Appendectomy in a Developing Community
}

\author{
Wilson IB Onuigbo* and PU Nze \\ Department of Pathology, The University of Nigeria Teaching Hospital, Nigeria
}

Submission: December 14, 2017; Published: January 03, 2018

*Correspondence Address: Wilson Onuigbo, Department of Pathology, The University of Nigeria Teaching Hospital, Enugu 400001, Nigeria,

Email: wilson.onuigbo@gmail.com

Abstract

There has been recent interest in USA concerning small bowel lymphoma. Therefore, this paper compares their findings especially as incidental appendectomy was included in biopsies undertaken in the Igbo Ethnic Group which is domiciled in the South Eastern Region of Nigeria. The notable difference was that perforation had not occurred in the local disease.

Keywords: Lymphoma; Small bowel; Perforation; Resection; Appendectomy; Childhood; Igbos

\section{Introduction}

Search of the literature revealed recent interest in USA as regards lymphoma in the small intestine [1-3]. Therefore, their findings have been compared with those of the Igbos [4], an Ethnic Group which is domiciled in South Eastern Nigeria. The work was facilitated by the local establishment of a histopathology data pool as was recommended by a Birmingham (UK) group [5].

\section{Investigation}

As the Pioneer Pathologist at the Reference Pathology Laboratory established by the Government of the Eastern Region of Nigeria at the capital city, Enugu, I encouraged local doctors to submit biopsy specimens provided that useful epidemiological data were supplied. On this account, two cases stood out over the years, especially as incidental appendectomy was also involved.

\section{Case Report}

\section{Case 1}

IS, a 3-year-old girl, was brought to The Queen Elizabeth Hospital, Umuahia, where she was seen by Dr. Okpara. There was a 3-weeks history of abdominal swelling. There was associated passing of scanty stool once in 2 days. Therefore, partial intestinal obstruction was suspected. Ascites continued to increase. Laparotomy was carried out. A tumor was found in the mid portion of the ileum as well as massive ascitic fluid. In addition, it was noted that the appendix was grossly enlarged, friable are edematous.
The junior author, Dr P. U. Nze, described the specimen nicely thus:

i. A pale mass weighing 350 gm and measuring $14 \mathrm{x} 9 \mathrm{x}$ $7 \mathrm{~cm}$. On section there is whitish friable tumor mass $5 \mathrm{~cm}$ across on the wall of the gut, thus narrowing the lumen.

ii. An appendix $13 \mathrm{~cm}$ long and $2.5 \mathrm{~cm}$ in diameter with the distal half covered with blood clots. On section the wall is uniformly whitish with scarcely any lumen. On microscopy, the senior author found the picture to be, in all areas, that of a small celled tumor of the lymphoid series. It grew in sheets partially replacing lymph node, small intestine, and appendix. Therefore, lymphoma was diagnosed.

\section{Case 2}

AC, a 4-year-old boy was seen by Dr. Onyemelukwe at the Orthopaedic Hospital, Enugu, because of a month's history of an abdominal mass. This was found on exploration to involve the jejunum and especially the base of the mesentery. There was also diffuse involvement of adjoining lymph nodes. Incidental appendectomy was performed. The specimens consisted of coils of intestine with both normal and heavily infiltrated areas. The appendix was $6 \mathrm{~cm}$ long and appeared normal. On microscopy, there was diffuse replacement of tissues including bowel and lymph nodes by small tumor cells of the lymphoid series. The appendix was normal. Diffuse lymphocytic lymphoma was diagnosed. 


\section{Discussion}

Sun's group admitted that, in China, primary intestinal lymphomas "are rarely reported and poorly characterized" [6]. German authors agreed with this view [7], and recommended resection. As for Italian workers [8], "Clinical findings are not specific, thus often determining a delay in the diagnosis." Although the present series is small, it is notable that perforation did not occur. In this context, it is notable that Vaidya and associates included perforation among factors that may affect treatment [2]. Incidentally, they included "limited resection of the tumor." Fortunately, this requirement was effected in this developing community.

\section{References}

1. Rawls RA, Vega KJ, Trotman BW (2003) Small bowel lymphoma. Curr Treat Options Gastroenterol 6(1): 27-34.

2. Vaidya R, Habermann TM, Donohue JH, Ristow KM, Maurer MJ, et al. (2013) Bowel perforation in intestinal lymphoma: Incidence and clinical features. Ann Oncol 24(9): 2439-2443.

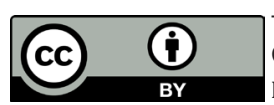

This work is licensed under Creative Commons Attribution 4.0 License

DOI: $10.19080 /$ CTOIJ.2018.08.555743
3. Cardona DM, Layne A, Lagoo AS (2012) Lymphomas of the gastrointestinal tract - Pathophysiology, pathology, and differential diagnosis. Indian J Pathol Microbiol 55(1): 1-16.

4. Basden GT (1966) Niger Ibos. Cass, London, UK.

5. Macartney JC, Rollaston TP, Codling BW (1980) Use of a histopathology data pool for epidemiological analysis. J Clin Pathol 33(4): 351-353.

6. Sun J, Lu Z, Yang D, Chen J (2011) Primary intestinal T-cell and NKcell lymphomas: A clinicopathological and molecular study from China focused on type II enteropathy-associated T-cell lymphoma and primary intestinal NK-cell lymphoma. Modern Pathol 24(7): 983-992.

7. Daum S, Ullrich R, Heise W, Dederke B, Foss HD, et al. (2003) Intestinal non-Hodgkin's lymphoma: A multicenter prospective clinical study from the German study group on intestinal non-Hodgkin's lymphoma. J Clin Oncol 21(14): 2740-2746.

8. Re GL, Federica V, Midiri F, Picone D, G Tona, M Galia, et al. (2016) Radiological features of gastrointestinal lymphoma. Gastroenterol Res Pract p. 9.

Your next submission with Juniper Publishers will reach you the below assets

- Quality Editorial service

- Swift Peer Review

- Reprints availability

- E-prints Service

- Manuscript Podcast for convenient understanding

- Global attainment for your research

- Manuscript accessibility in different formats ( Pdf, E-pub, Full Text, Audio)

- Unceasing customer service

Track the below URL for one-step submission https://juniperpublishers.com/online-submission.php 